\title{
Psychological Contract Fulfilment And Well-Being
}

\author{
Mohamad Irwan Ahmad \\ Deceased \\ Centre for Occupational and Health Psychology, \\ School of Psychology, Cardiff University, \\ 63 Park Place, Cardiff CF10 3AS, UK \\ Kirsty Firman \\ Centre for Occupational and Health Psychology, \\ School of Psychology, Cardiff University, \\ 63 Park Place, Cardiff CF10 3AS, UK \\ Hugo Smith \\ Centre for Occupational and Health Psychology, \\ School of Psychology, Cardiff University, \\ 63 Park Place, Cardiff CF10 3AS, UK \\ Andrew P. Smith \\ Centre for Occupational and Health Psychology, \\ School of Psychology, Cardiff University, \\ 63 Park Place, Cardiff CF10 3AS, UK
}

\begin{abstract}
Background: There is considerable literature on well-being at work, the well-being process and short measures of psychosocial concepts. Psychological Contract Fulfilment (PCF) and other employee attitudes and behaviours have also been widely studied. Aims and objectives: The aim of the present study was to examine associations of short measures of PCF and well-being outcomes while statistically adjusting for other established predictors (job characteristics, coping styles and personality). Methods: The survey included established measures of well-being and the newly developed PCF short items. The questions were presented in an online survey, delivered using Qualtrics software and given to 166 workers from the USA, who were recruited using Mechanical Turk. Results: Factor analyses identified the following measures: negative job characteristics; positive work characteristics; positive and negative coping; positive personality; PFC; work behaviours and job attitudes; work-life balance; and positive and negative well-being. While the PFC variables were significantly associated with well-being outcomes in univariate analyses, these effects were no longer significant when established predictors were included in the analyses. Conclusion: Effects attributed to PFC may reflect other organisational and individual variables. The new short items can be used in future studies of the well-being of workers. This will lead to an increase in our knowledge and the development of new models that can be of theoretical and practical significance.
\end{abstract}

Key words: Wellbeing; Psychological Contract Fulfilment; Organisational Commitment; Citizenship Behaviour; Intention to Quit; Job Security; Work Effort; Work Life Balance

\section{INTRODUCTION}

There has been considerable research on well-being at work and one recent development has been the use of the Demands-Resources-Individual Effects (DRIVE) model (Mark \& Smith, 
2008). This model was initially developed to examine the stress process. Mark and Smith (2008) suggest that it is desirable to have a model that includes negative and positive job characteristics, individual experiences, and subjective appraisals of perceived stress and job satisfaction. The variables were categorised as work demands, work resources (e.g. control, support), individual differences (e.g. coping style, attributional style), and outcomes. The model was intended as a framework into which any relevant variables could be included and in the present study variables related to Psychological Contract Fulfilment (PCF) were included.

Another methodological feature of this well-being research has been to develop short measures that are highly correlated with longer validated scales (Williams, 2015; Williams and Smith, 2012, 2018a, 2018b, 2018c; Williams et al., 2017; Williams, Pendlebury, \& Smith, 2017; Williams, Thomas, \& Smith, 2017). These short measures were shown to be highly correlated with the longer scales, and the correlation was often greater than those between single items and scale totals from the longer measures. The single items were also shown to have the same predictive validity as the longer versions and had good test-re-test reliability. Additional variables have been added to the DRIVE model (e.g. ethnicity variables - Capasso, Zurlo, \& Smith, 2016, 2016b, 2016c, 2018; Zurlo, Vallone, \& Smith, 2018; role conflict, change and bullying - Smith et al., 2009), as have short items related to well-being (e.g. cognitive fatigue Smith, 2018; training attitudes - Nor \& Smith, 2018; health-related behaviours, absenteeism, presenteeism and musculoskeletal disorders - Fan \& Smith, 2017; Smith \& Smith, 2017; noise and academic attainment - Smith, 2017; quality of life and strategies for working away - Smith, Smith, \& Jelley, 2018).

The Psychological Contract is the exchange relationship between the organisation and employee where the employee offers an obligation to the organisation and the organisation in return will appreciate this obligation with some terms and agreement (Rousseau, 1989). When a breach of the Psychological Contract occurs, employees may exhibit negative emotions such as anger, disappointment and betrayal and may cease to work efficiently and intend to quit the organisation (Robinson et al., 1994). The model proposed by Guest (1989) describes the attitudinal and behavioural effects related to changes in the Psychological Contract (Background factors: individual; organisational. State: fairness; trust; "the delivery of the deal". Attitudinal consequences: organisational commitment; work satisfaction; employment relations; work-life balance; job security. Behavioural consequences: motivation; organisational citizenship; and intention to stay/quit). There is little research examining key antecedents and consequences of the PCF in the same study. Similarly, there is a lack of research examining the effect of PCF on well-being. Most of the research on PCF has explored attitudes and behavioural outcomes, but very little has looked at the well-being of employees.

A key variable in PCF is Organisational Commitment (OC) which refers to the employee's attitudes and behaviours that can help the organisation to achieve its goals and at the same time maintains the strong desire of the employee to stay as a member of the organisation (Steers, 1977). There has been some previous research on OC and well-being (Coetzee \& Rothmann, 2005; Nikolaou \& Tsaousis, 2002; Panaccio \& Vandenberghe, 2009; Siu, 2002), with results confirming that high $\mathrm{OC}$ is associated with greater well-being. Another key variable in this research has been work-life balance (WLB) which has been defined as the absence of conflict between work and personal/family matters (Frone, 2003; Frone et al., 1992; Quick et al., 2004). There is extensive research showing that WLB influences well-being (Feigon et al., 2018; Haar et al., 2014; Yu, Manku, \& Backman, 2018), with good WLB being associated with greater well-being. 
Job security was also examined in the present study. Job security has been defined as a state where the individual feels secure in their current job. Again, there is an extensive literature confirming the associations between job security and well-being (De Witte, 1999; De Witte et al., 2016; Schaufeli, 2016; De Witte et al., 2015; Silla et al., 2009; Stiglbauer et al., 2012; De Cuyper et al., 2008; De Cuyper and De Witte, 2007). Job satisfaction, another a consequence of PCF, was also included in the present study. Job satisfaction also plays a key role in models of well-being at work (see the DRIVE model).

The behavioural effects of PCF include motivation, effort, organisational citizenship behaviour and intention to quit. Motivational processes play a key role in adaptation to the workplace and reaction to stress (Fernet \& Austin, 2014). Changes in motivation have been associated with changes in well-being at work (Bjorklund et al., 2013). Work effort has been defined as the amount of energy employees put in to be able to work successfully (Ilgen \& Klein, 1989). A work-effort recovery mechanism is involved in the associations between sleep quality, adverse work conditions, rumination, after-work fatigue and well-being (Kompier et al., 2012).

Organisational Citizenship Behaviour (OCB) has 5-dimensions, namely altruism, conscientiousness, courtesy, civic virtue, and sportsmanship. Altruism can be defined as helping or helpfulness (Organ, 1997). Conscientiousness is referred to as discretionary behaviour that goes beyond the minimum roles at work such as working hard, not taking extra breaks, and obeying the rules and regulations of the organisations (Podsakoff et al., 1990).

Courtesy refers to the employee's behaviours and gestures that help others with any interpersonal and work-related problems (Organ, 1990). Civic virtue refers to the employee's constructive involvement in the organisational political process (Tambe \& Shanker, 2014).

Sportsmanship is referred to as "a willingness to tolerate the inevitable inconveniences and impositions of work without complaining." (Organ, 1990). There has been previous research on OCB and well-being (Boyd \& Nowell, 2017; Dávila \& Finkelstein, 2013; Kumar et al., 2016). OCB targeted at other individuals was found to be positively correlated with relatedness need satisfaction whereas OCB towards the organisation was positively related with psychological health.

The final measure of the behavioural consequences of PCF used here was intention to quit. Intention to quit can be defined as an employee's aim to quit from the current organisation and to search for another job in the near future (Weisberg, 1994). Negative job characteristics are often associated with a stronger intention to quit (Saucan et al., 2014; Grebner et al., 2003) whereas organizational resources supportive of better WLB have been associated with lower intention to quit scores (Burke et al., 2003).

Initial analyses of data from the present study aimed to combine the various components of PCF with well-being at work (Ahmad et al., 2018). The results showed that short measures on the antecedents and consequences of PCF were highly correlated with established longer measures. Univariate analyses also showed that the PCF measures were associated with components of the DRIVE model. The aim of the present analysis was to examine associations of short measures of PCF and well-being outcomes while statistically adjusting for other established predictors (job characteristics, work resources, coping styles and personality).

\section{METHOD}

This study was carried out with the approval of the Ethics Committee, School of Psychology, Cardiff University, and the informed consent of the volunteers. 


\section{Participants}

The participants were 166 workers from the USA recruited using Mechanical Turk. Details of their demographics and job characteristics are shown in Table 1.

Table 1

Respondents' Demographic Profile

\begin{tabular}{|c|c|c|c|}
\hline Variable & Response Category & Frequency & Percentage (\%) \\
\hline \multirow[t]{5}{*}{ Age } & $20-30$ years & 54 & 32.5 \\
\hline & $31-40$ years & 68 & 41.0 \\
\hline & 41-50 years & 21 & 12.7 \\
\hline & $51-60$ years & 11 & 6.6 \\
\hline & $61-70$ years & 12 & 7.2 \\
\hline \multirow[t]{2}{*}{ Sex } & Male & 96 & 57.8 \\
\hline & Female & 70 & 42.2 \\
\hline \multirow[t]{6}{*}{ Marital status } & Single & 59 & 35.5 \\
\hline & Living with partner & 29 & 17.5 \\
\hline & Married & 67 & 40.4 \\
\hline & Separated & 3 & 1.8 \\
\hline & Divorced & 7 & 4.3 \\
\hline & Widowed & 1 & 0.6 \\
\hline \multirow[t]{4}{*}{ Education } & Undergraduate Degree & 108 & 65.1 \\
\hline & Post-Graduate Degree & 51 & 30.7 \\
\hline & Doctorate (PhD) & 4 & 2.4 \\
\hline & Other & 3 & 1.8 \\
\hline \multirow[t]{7}{*}{ Race } & White & 135 & 81.3 \\
\hline & Black Caribbean & 4 & 2.4 \\
\hline & Black African & 10 & 6.0 \\
\hline & Black neither Caribbean or African & 5 & 3.0 \\
\hline & Indian & 3 & 1.8 \\
\hline & Chinese & 4 & 2.4 \\
\hline & Other & 5 & 3.0 \\
\hline \multirow[t]{2}{*}{ Work sector } & Public & 68 & 41.0 \\
\hline & Private & 98 & 59.0 \\
\hline \multirow[t]{7}{*}{ Yearly income $(E)$} & $<10000$ & 3 & 1.8 \\
\hline & $10001-20000$ & 13 & 7.8 \\
\hline & $20001-30000$ & 28 & 16.9 \\
\hline & $30001-40000$ & 38 & 22.9 \\
\hline & $40001-50000$ & 24 & 14.5 \\
\hline & $50001-60000$ & 23 & 13.9 \\
\hline & 60001> & 37 & 22.3 \\
\hline \multirow[t]{5}{*}{ General health } & Very good & 36 & 21.7 \\
\hline & Good & 97 & 58.4 \\
\hline & Fair & 28 & 16.9 \\
\hline & $\mathrm{Bad}$ & 5 & 9.04 \\
\hline & Very bad & 0 & 0.0 \\
\hline
\end{tabular}

\section{The Survey}

An online survey was carried out using Qualtrics software. The complete survey is available at the link shown below and the measures summarised in the next section.

https://www.researchgate.net/publication/329311391_SURVEY_-

SHORT_MEASURES_OF_ORGANISATIONAL_COMMITMENT_CITIZENSHIP_BEHAVIOUR_AND_0 THER_EMPLOYEE_ATTITUDES_AND_BEHAVIOURS_ASSOCIATIONS_WITH_WELL-BEING 


\section{Measures}

Factor analyses led to the groups of variables shown in Table 2 (with their factor loadings).

\section{Stages of Analysis}

\section{RESULTS}

There were two main stages in the analyses. The first examined associations between the PCF factor scores (PCF; work behaviours; job attitudes and WLB) and the well-being outcomes. The second examined these associations adjusting for the effects of the established predictors (negative work characteristics; positive work characteristics; positive coping; negative coping and personality).

\section{Univariate Analyses}

PCF was significantly correlated with both positive $(r=0.43)$ and negative outcomes $(r=-$ 0.59 ). This was also found for work behaviours (positive outcomes: $r=0.57$; negative outcomes: $r=-0.42$ ), job attitudes (positive outcomes: $r=0.41$; negative outcomes: $r=-0.4$ ) and WLB (positive outcomes: $r=0.32$; negative outcomes: $r=-0.46$ ).

\section{Multi-variate Regressions}

Table 3 shows the significant predictors of positive well-being when PCF was included in the regression. High levels of well-being were predicted by a positive personality, positive coping and positive work characteristics. Poor health was associated with lower positive well-being. PCF had no significant effect. 
Table 2

Factor structure of the antecedents and outcomes of PCF.

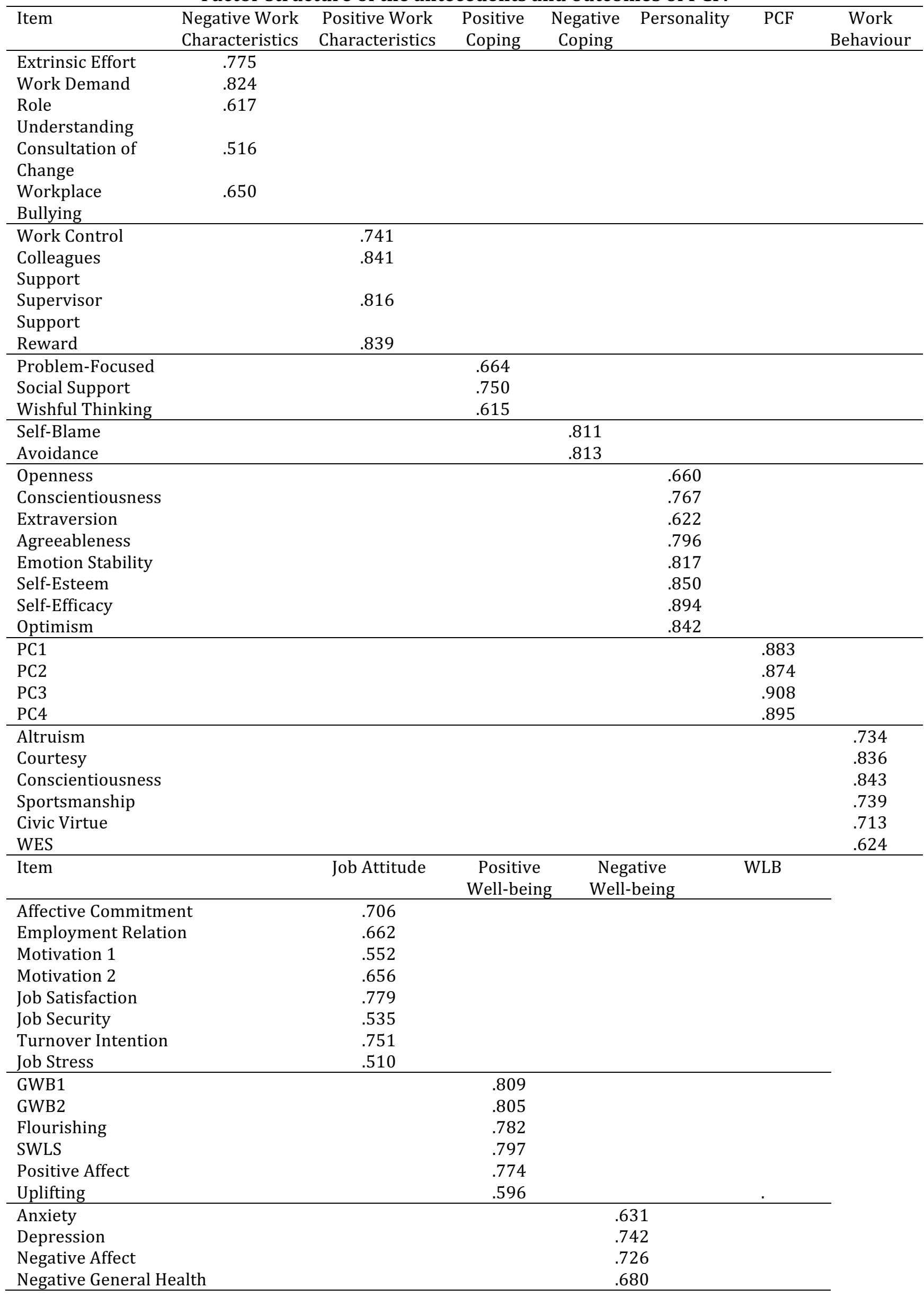




\begin{tabular}{lc}
\hline Life Interferes Work (WLB) & .657 \\
Work Interferes Life (WLB) & .535 \\
Outside Work Stress 1 & .811 \\
Outside Work Stress 2 & .730 \\
Hassle & .467 \\
\hline
\end{tabular}

Table 3

PFC and predictors of positive well-being

\begin{tabular}{lccccccc}
\hline Variable & Beta & S.E. & $\begin{array}{c}\text { Standardised } \\
\text { beta }\end{array}$ & $\mathrm{t}$ & Sig. & $\begin{array}{c}\text { CI } \\
\text { 95\% lower } \\
\text { bound }\end{array}$ & $\begin{array}{c}\text { CI } \\
\text { 95\% upper } \\
\text { bound }\end{array}$ \\
\hline (Constant) & -.002 & .526 & & -.005 & .996 & -1.041 & 1.036 \\
Health Status & -.186 & .086 & -.139 & -2.154 & .033 & -.357 & -.015 \\
+ve Work & .240 & .071 & .240 & 3.405 & .001 & .101 & .380 \\
Characteristic & .245 & .082 & .245 & 2.990 & .003 & .083 & .406 \\
+ve Coping & .502 & .095 & .502 & 5.293 & .000 & .315 & .690 \\
Personality & .079 & .079 & .079 & .998 & .320 & -.077 & .235 \\
PCF & & & & & & & \\
\hline
\end{tabular}

A similar analysis was carried out including work behaviours, job attitudes and WLB factor scores. Work behaviour and WLB were no longer significant when the established predictors were included (see Table 4). In the case of job attitudes, these now showed the opposite pattern of association to the univariate analysis, with high job attitude scores going with reduced well-being.

Table 4

Attitudes, Behaviours, WLB and Predictors of Positive Well-being

\begin{tabular}{lccccccc}
\hline Variable & Beta & S.E. & $\begin{array}{c}\text { Standardised } \\
\text { beta }\end{array}$ & $\mathrm{t}$ & Sig. & \multicolumn{2}{c}{ CI 95\% } \\
lower bound & CI 95\% upper \\
bound
\end{tabular}

These analyses were repeated using the negative well-being outcomes as dependent variables. Again, PCF was no longer significant (see Table 5) and neither were work behaviours or job attitudes. Good WLB remained negatively associated with the negative outcomes (see Table 6).

Table 5

PFC and Predictors of Negative Well-being

\begin{tabular}{lccccccc}
\hline Variable & Beta & S.E. & $\begin{array}{c}\text { Standardised } \\
\text { beta }\end{array}$ & $\mathrm{t}$ & Sig. & $\begin{array}{c}\text { CI } \\
\text { 95\% lower } \\
\text { bound }\end{array}$ & $\begin{array}{c}\text { CI } \\
\text { 95\% upper } \\
\text { bound }\end{array}$ \\
\hline (Constant) & -2.012 & .423 & & -4.759 & .000 & -2.847 & -1.176 \\
Sick Leave & .191 & .081 & .146 & 2.364 & .019 & .031 & .351 \\
Health Status & .600 & .085 & .448 & 7.090 & .000 & .433 & .768 \\
-ve Work & .191 & .069 & .191 & 2.776 & .006 & .055 & .327 \\
Characteristic & .277 & .066 & .277 & 4.188 & .000 & .146 & .408 \\
-ve Coping & .211 & .080 & .211 & 2.644 & .009 & .053 & .369 \\
+ve Coping & .063 & .077 & .063 & .820 & .413 & -.089 & .215 \\
PFC & & & & & & &
\end{tabular}


Table 6

Attitudes, Behaviours, WLB and Predictors of Negative Well-being

\begin{tabular}{lccccccc}
\hline Variable & Beta & S.E. & $\begin{array}{c}\text { Standardised } \\
\text { beta }\end{array}$ & $\mathrm{t}$ & Sig. & $\begin{array}{c}\text { CI } \\
\text { 95\% lower } \\
\text { bound }\end{array}$ & $\begin{array}{c}\text { CI } \\
\text { boupper } \\
\text { bound }\end{array}$ \\
\hline (Constant) & -2.049 & .482 & & -4.247 & .000 & -3.002 & -1.096 \\
Health Status & .571 & .082 & .426 & 6.930 & .000 & .408 & .733 \\
-ve Work & .388 & .078 & .388 & 4.982 & .000 & .234 & .543 \\
Characteristic & .336 & .063 & .336 & 5.337 & .000 & .212 & .461 \\
-ve Coping & .189 & .075 & .189 & 2.525 & .013 & .041 & .336 \\
+ve Coping & .061 & .075 & .061 & .819 & .414 & -.086 & .209 \\
Job Attitude & .138 & .078 & .138 & 1.763 & .080 & -.017 & .292 \\
Work & -.350 & .068 & -.350 & -5.161 & .000 & -.483 & -.216 \\
Behaviour & & & & & &
\end{tabular}

\section{DISCUSSION}

The aim of the research described here was to integrate research on PCF and well-being. Two models were used to address this issue. The DRIVE model (Mark \& Smith, 2008) was used to represent the well-being process. This model includes job demands, job resources, individual differences, job appraisals (perceived stress and job satisfaction) and positive and negative outcomes. The Guest (1989) model includes background factors such as characteristics of the individual and organisation, and then describes PCF in terms of Fairness, Trust and the "Delivery of the Deal". Attitudinal consequences of PCF follow and these include OC, job satisfaction, employment relations, WLB and job security. The behavioural consequences associated with PCF include increased motivation, organisational citizenship and increased intention to stay in the job.

In our previous paper (Ahmad et al., 2018) we described the development of short items measuring aspects of PCF and the attitudinal and behavioural consequences. These were validated by examining correlations with the original longer scales from which they were developed. The results revealed high correlations (often in the range of 0.7-0.8) between the new short items and the longer versions. PCF was negatively correlated with negative job characteristics and was positively correlated with job resources. PCF was negatively correlated with avoidance coping and was positively correlated with the Big 5 dimensions of personality (openness; conscientiousness; extraversion; agreeableness; and emotional stability) and the positive personality dimensions of self-esteem, self-efficacy, and optimism.

The analyses presented in the present article showed that PCF, job attitudes, work behaviours and WLB were associated with positive outcomes and negatively correlated with the negative outcomes. However, when the established predictors of well-being (job characteristics, coping and personality) were included in the regressions, the associations between PCF, job attitudes and work behaviours and well-being were no longer significant. This finding confirms the results obtained by Smith and Smith (2017) when they used very short measures of the wellbeing process and PCF.

The present study was intended to form the basis for future research by developing integrating models of well-being and PCF. The important contribution of the present article was conducting multi-variate analyses to determine whether PCF and its attitudinal and behavioural consequences are associated with well-being outcomes when organisational and individual factors are statistically controlled. The present study had a cross-sectional design which makes it difficult to assign causality. Future research should use a longitudinal design, preferably with interventions aimed at improving PCF and the consequences of it. It is also 
important to know whether the present results generalise to other samples of workers in different countries.

\section{References}

Bjorklund, C., Jensen, I., \& Lohela-Karlsson, M. (2013). Is a change in work motivation related to a change in mental well-being? Journal of Vocational Behavior, 83(3), 571-580. doi: 10.1016/j.jvb.2013.09.002

Boyd, N. M., \& Nowell, B. (2017). Testing a theory of sense of community and community responsibility in organizations: an empirical assessment of predictive capacity on employee wellbeing and organisational citizenship. Journal of Community Psychology, 45(2), 210-229. doi: 10.1002/jcop.21843

Burke, R. J., Oberklaid, F., \& Burgess, Z. (2003). Organizational values, work experiences, and satisfactions among Australian psychologists. The International Journal of Organizational Analysis, 11(2), 123-135. doi: 10.1108/eb028966

Capasso, R., Zurlo, M.C., Smith , A.P. (2016a). Ethnicity and stress at work: A literature review and suggestions for future research. British Journal of Education, Society \& Behavioural Science, 15(1): 1-20.

DOI : 10.9734/BJESBS/2016/24340

Capasso, R., Zurlo, M.C. and Smith, A.P. (2016b). Ethnicity and work-related stress in Eastern European care workers for the elderly: an application of a proposed multi-dimensional model. Diversity and Equality in Health and Care, 13(2): 197-205.

Capasso, R., Zurlo, M.C. \& Smith, A.P. (2016c). Ethnicity, work-related stress and subjective reports of health by migrant workers: a multi-dimensional model. Ethnicity and Health, 23(2), 174-193. http://dx.doi.org/10.1080/13557858.2016.1258041

Capasso, R., Zurlo, M.C. and Smith, A.P. (2018). Stress in factory workers in Italy: an application of the Ethnicity and work-related stress model in Moroccan factory workers. Psychology and Developing Societies, 30(2), 1-34. DOI: $10.1177 / 0971333618783397$.

Coetzee, S. E., \& Rothmann, S. (2005). Occupational stress, organisational commitment and ill-health of employeesat a higher education institution in South Africa. SA Journal of Industrial Psychology, 31(1), 47-54. doi: 10.4102/sajip.v31i1.179

Dávila, M. C., \& Finkelstein, M. A. (2013). Organizational citizenship behavior and well-being: Preliminary results. International Journal of Applied Psychology, 3(3), 45-51. doi: 10.5923/j.ijap.20130303.03

De Cuyper, N., Bernhard-Oettel, C., Berntson, E., De Witte, H., \& Alarco, B. (2008). Employability and employees' well-being: Mediation by job insecurity. Applied Psychology: An International Review, 57(3), 488-509. doi: 10.1111/j.1464-0597.2008.00332.x

De Cuyper, N., \& De Witte, H. (2007). Job insecurity in temporary versus permanent workers: Associations with attitudes, well-being, and behaviour. Work \& Stress, 21(1), 65-84. doi: 10.1080/02678370701229050

De Witte, H. (1999). Job insecurity and psychological well-being: Review of the literature and exploration of some unresolved issues. European Journal of Work and Organizational Psychology, 8(2), 155-177. doi: $10.1080 / 135943299398302$

De Witte, H., Pienaar, J., \& De Cuyper, N. (2016). Review of 30 years of longitudinal studies on the association between job insecurity and health and well-being: Is there causal evidence? Australian Psychologist, 51(1), 18-31. doi: 10.1111/ap.12176

De Witte, H., Vander Elst, T., \& De Cuyper, N. (2015). Job insecurity, health and well-being. In J. Vuori, R. Blonk, \& R. H. Price (Eds.), Aligning perspectives on health, safety and wellbeing. Sustainable working lives: Managing work transitions and health throughout the life course (pp. 109-128). New York, NY, US: Springer Science + Business Media; US. doi: 10.1007/978-94-017-9798-6_7

Fan, J. \& Smith, A.P. 2017. The impact of workload and fatigue on performance. In L. Longo and M.C. Leva (eds) Human Mental Workload: Models and Applications. H-WORKLOAD 2017. Communications in Computer and Information Science, vol 726. Springer, Cham. Pp 90 - 105. DOI: 10.1007/978-3-319-61061-0_6

Feigon, M., Block, C., Guidotti Breting, L., Boxley, L., Dawson, E., \& Cobia, D. (2018). Work-life integration in neuropsychology: A review of the existing literature and preliminary recommendations. The Clinical Neuropsychologist, 32(2), 300-317. doi: 10.1080/13854046.2017.1411977 
Fernet, C., \& Austin, S. (2014). Self-determination and job stress. In M. Gagne(Ed), The Oxford handbook of work engagement, motivation, and self-determination theory (pp. 231-244). New York, NY, US: Oxford University Press; US.

Frone, M. R. (2003). Work-family balance. In J. C. Quick \& L. E. Tetrick (Eds.), Handbook of Occupational Health Psychology (pp. 143-162). Washington, DC: American Psychological Association.

Frone, M. R., Russell, M., \& Cooper, M. L. (1992). Antecedents and outcomes of work-family conflict: Testing a model of the work-family interface. Journal of Applied Psychology, 77, 65-78. doi: 10.1037//0021-9010.77.1.65

Grebner, S., Semmer, N. K., Lo Faso, L., Gut, S., Kalin, W., \& Elfering, A. (2003). Working conditions, well-being, and job-related attitudes among call centre agents. European Journal of Work and Organizational Psychology, 12(4), 341-365. doi: 10.1080/13594320344000192

Guest, D. E. (1989). “Is the psychological contract worth taking seriously?”. Journal of Organisational Behaviour, 19(1), 649-664. doi: 10.1002/(sici)1099-1379(1998)19:1+<649::aid-job970>3.0.co;2-t

Haar, J. M., Russo, M., Sune, A., \& Ollier-Malaterre, A. (2014). Outcomes of work-life balance on job satisfaction, life satisfaction and mental health: A study across seven cultures. Journal of Vocational Behavior, 85(3), 361-373. doi: 10.1016/j.jvb.2014.08.010

Ilgen, D. R., \& Klein, H. J. (1989). Organizational behavior. In M.R. Rosenzweig \& L.W. Porter (Eds.), Annual Review of Psychology (Vol. 40, pp. 327-51). Palo Alto, CA: Annual Reviews.

Kompier, M. A. J., Taris, T. W., \& van Veldhoven, M. (2012). Tossing and turning-Insomnia in relation to occupational stress, rumination, fatigue, and well-being. Scandinavian Journal of Work, Environment \& Health, 38(3), 238-246. doi: 10.5271/sjweh.3263

Kumar, M., Jauhari, H., \& Singh, S. (2016). Organizational citizenship behavior \& employee well-being. Indian Journal of Industrial Relations, 51(4), 594-608.

Mark, G. M., \& Smith, A. P. (2008). Stress models: A review and suggested new direction. In J. Houdmont \& S. Leka (Eds.), Occupational Health Psychology: European Perspectives on Research, Education and Practice (Vol. 3, pp. 111-144). Nottingham: Nottingham University Press.

Ahmad M.I. \& Firman K. \& Smith H. \& Smith A. 2018. Short Measures Of Organisational Commitment, Citizenship Behaviour And Other Employee Attitudes And Behaviours: Associations With Well-Being, BMIJ, (2018), 6(3): 516550 doi: http://dx.doi.org/10.15295/bmij.v6i3.391

Nikolaou, I., \& Tsaousis, I. (2002). Emotional intelligence in the workplace: Exploring its effects on occupational stress and organizational commitment. The International Journal of Organizational Analysis, 10(4), 327-342. doi: $10.1108 / \mathrm{eb} 028956$

Nor, NIZ \& Smith, A.P. (2018). Attitudes to Training and Its Relation to the Well-being of Workers. Journal of Education, Society and Behavioural Science, 27(2): 1-19, 2018; Article no.JESBS.44445 ISSN: 2456-981X. DOI: 10.9734/JESBS/2018/44445

Organ, D. W. (1990). The subtle significance of job satisfaction. Clinical Laboratory Management Review, 4(1), 9498.

Organ, D. W. (1997). Organizational citizenship behaviour: It's construct clean-up time. Human Performance, 10(2), 85-97. doi: 10.1207/s15327043hup1002_2

Panaccio, A., \& Vandenberghe, C. (2009). Perceived organizational support, organizational commitment and psychological well-being: A longitudinal study. Journal of Vocational Behavior, 75(2), 224-236. doi: 10.1016/j.jvb.2009.06.002

Podsakoff, P. M., MacKenzie, S. B., Moorman, R. H., \& Fetter, K. (1990). Transformational leader behaviours and their effects on followers' trust in leader, satisfaction, and organizational citizenship behaviours. The Leadership Quarterly, 1(2), 107-142. doi: 10.1016/1048-9843(90)90009-7

Quick, J. D., Henley, A. B., \& Quick, J. C. (2004). The balancing act: At work and at home. Organizational Dynamics, 33(4), 426-438. doi: 10.1016/j.orgdyn.2004.09.008

Robinson, S. L., Kraatz, M., \& Rousseau, D. M. (1994). Changing obligations and the psychological contract: A longitudinal study. Academy of Management Journal, 37(1), 137-152. doi: 10.2307/256773

Rousseau, D. M. (1989). Psychological and implied contract in organisations. Employee Responsibilities and Rights Journal, 2(2), 121-139. doi: 10.1007/bf01384942 
Saucan, D. S., Marhan, A. M.,\& Micle, M. I. (2014). Intention to quit job-Consequence of work-family conflict. A Romanian pilot study. Revista de Psihologie, 60(3), 253-259.

Schaufeli, W. B. (2016). Job insecurity research is still alive and kicking twenty years later: A commentary. Australian Psychologist, 51(1), 32-35. doi: 10.1111/ap.12201

Silla, I., De Cuyper, N., Gracia, F. J., Peiro, J. M., \& De Witte, H. (2009). Job insecurity and well-being: Moderation by employability. Journal of Happiness Studies, 10(6), 739-751. doi: 10.1007/s10902-008-9119-0

Siu, O. L. (2002). Occupational stressors and well-being among Chinese employees: The role of organisational commitment. Applied Psychology, 51(4), 527-544. doi: 10.1111/1464-0597.t01-1-00106

Smith, A.P. (2017). Perceptions of noise exposure, wellbeing and academic attainment of university students. ICBEN 2017.

Smith, A.P. (2018). Cognitive fatigue and the well-being and academic attainment of university students. Journal of Education, Society and Behavioral Science. DOI: 10.9734/JESBS/2018/39529

Smith, A.P. \& Smith, H.N. 2017. A short questionnaire to measure wellbeing at work (Short-SWELL) and to examine the interaction between the employee and organisation. In: Charles, R. \& Wilkinson, J. eds. Contemporary Ergonomics and Human Factors 2017. Chartered Institute of Ergonomics and Human Factors. ISBN: 978-1-52720762-2. Pg 200-205.

Smith, A.P., Smith, H.N. \& Jelley, T. (2018). Studying Away Strategies: Well-being and Quality of University

Life of International Students in the UK. Journal of Education, Society and Behavioural Science, 26(4), Article no.JESBS.43377. ISSN: 2456-981X. DOI: 10.9734/JESBS/2018/43377

Smith, A., Wadsworth, E., Chaplin, K., Allen, P., \& Mark, G. (2009). What is a good job? The relationship between work/working and improved health and well-being. Wigston, UK: IOSH.

Steers, R. M. (1977). Antecedents and Outcomes of Organizational Commitment. Administrative Science Quarterly, 22(1), 46-56. doi: 10.2307/2391745

Stiglbauer, B., Selenko, E., Batinic, B., \& Jodlbauer, S. (2012). On the link between job insecurity and turnover intentions: Moderated mediation by work involvement and well-being. Journal of Occupational Health Psychology. 17(3), 354-364. doi: 10.1037/a0028565

Tambe, S., \& Shanker, M. (2014). A study of organisational citizenship behaviour and its dimensions: A literature review. International Research Journal of Business and Management, 1, 67-73.

Weisberg, J. (1994). Measuring workers' burnout and intention to leave. International Journal of Manpower, 15(1), 4-14. doi: 10.1108/01437729410053590

Williams G.M (2015) Researching and developing mental health and wellbeing assessment tools for supporting employees and employers in Wales. http://orca.cf.ac.uk/71443/1/2015williamsphd.pdf

Williams, G.M. \& Smith, A.P. (2012). A holistic approach to stress and well-being. Part 6: The Wellbeing Process Questionnaire (WPQ Short Form). Occupational Health (At Work), 9(1), 29-31.

Williams, G., Pendlebury, H., Thomas, K \& Smith, A.P. 2017. The student wellbeing process questionnaire (Student WPQ). Psychology, 8, 1748-1761 http://doi.org/10.4236/psych.2017.811115

Williams, G., Pendlebury, H. \& Smith, A.P. 2017. Stress and Well-being of Nurses: an Investigation using the Demands-Resources- Individual Effects (DRIVE) model and Well-being Process Questionnaire (WPQ). Jacobs Journal of Depression and Anxiety,1, 1-8.

http://depressionandanxiety.jacobspublishers.com/images/Depression/J_J_Depr_Anxi_1_1_001.pdf

Williams, G., Thomas, K \& Smith, A.P. 2017. Stress and Well-being of University Staff: an Investigation using the Demands-Resources- Individual Effects (DRIVE) model and Well-being Process Questionnaire (WPQ). Psychology, 8, 1919-1940. https://doi.org/10.4236/psych.2017.812124

Williams, G.M. \& Smith, A.P. 2018a. A practical method of predicting wellbeing at work: the Wellbeing Process Tool. Advances in Social Sciences Research Journal, 5(2), 86-93. doi: 10.14738/assrj.52.4158.

http://scholarpublishing.org/index.php/ASSRJ/article/view/4158/2506

Williams, G.M. \& Smith, A.P. 2018b. A longitudinal study of the well-being of students using the student well-being questionnaire (WPQ). Journal of Education, Society and Behavioral Science, 24(4), 1-6.

doi:10.9734/JESBS/2018/40105 
Williams, G.M. \& Smith, A.P. 2018c. Diagnostic validity of the anxiety and depression questions from the WellBeing Process Questionnaire. Journal of Clinical and Translational Research. doi: 10.18053/jctres.04.201802.001

Yu.Y., Manku, M., \& Backman, C. L.(2018). Measuring occupational balance and its relationship to perceived stress and health. Canadian Journal of Occupational Therapy / Revue Canadienne D'Ergotherapie, 85(2), 117-127. doi: $10.1177 / 0008417417734355$

Zurlo, M.C., Vallone, F. \& Smith, A.P. (2018). Effects of Individual Differences and Job Characteristics on the Psychological Health of Italian Nurses. Europe's Journal of Psychology, 14 (1), 159-175. doi:

10.5964/ejop.v14i1.1478 